\title{
SHARE REPURCHASES AND THE FLEXIBILITY HYPOTHESIS
}

\author{
Subramanian Rama Iyer ${ }^{\mathrm{a}}$, Ramesh P. Rao ${ }^{\mathrm{b}}$
}

${ }^{a}$ Department of Finance, Anderson School of Management, University of New Mexico, Albuquerque, NM 87111. Email: sriyer@unm.edu

${ }^{\mathrm{b}}$ Department of Finance, Spears School of Business, Oklahoma State University, Stillwater, OK 74078. Email: ramesh.rao@okstate.edu Tel:405-744-1385 


\title{
SHARE REPURCHASES AND THE FLEXIBILITY HYPOTHESIS
}

\author{
Abstract \\ Extant research has found that firms are increasingly substituting dividends with share \\ repurchases. This substitution effect is largely attributed to the flexibility offered by share \\ repurchases.. This paper tests two types of flexibilities associated with repurchases-operational \\ and reactive flexibility. Operational flexibility refers to the choice between share repurchases and \\ dividends. Firms consider dividends to be rigid and share repurchases to be flexible. Without fear \\ of an adverse market reaction firms can choose not repurchase shares, which is not possible with \\ dividends. Reactive flexibility refers to the flexibility offered by share repurchases to alter an \\ ongoing open market share repurchase program. Using the financial crisis period of 2008-2009 \\ as a natural experiment we test for evidence of both operational and reactive flexibilities \\ associated with share repurchases. We find that share repurchasers are more flexible than \\ dividend payers thereby proving operational flexibility. We also find that share repurchasers \\ have the ability to alter their ongoing open market share repurchase program, thereby proving \\ reactive flexibility.
}




\section{Introduction}

Firms distribute cash through dividends and through share repurchases. Over the last two decades share repurchases have become increasingly popular and dividends less so. One of the key differentiating factors between dividends and share repurchases is the potential flexibility offered by the latter. Brav, Graham, Harvey and Michaely (2005) survey financial executives and find that managers like the flexibility of share repurchases and dislike the rigidity of dividends. Respondents were asked to pick between dividends and share repurchases if they were initiating a payout. Two-thirds of managers prefer share repurchases over dividends. Due to the rigidity of dividends, firms shy away from dividend initiations. Once a firm initiates a dividend, it is expected to continue to pay dividends. Initiating firms are expected to build the credibility of paying regular dividends in future periods. This expectation acts as a deterrent for non-dividend paying firms to initiate dividend payouts. However, share repurchases are not viewed as being subject to a similar expectation. While most managers agree that reducing dividends will draw negative abnormal market reaction, only a small proportion of financial executives consider that reducing repurchases will have such adverse consequences ${ }^{1}$.

Consistent with the reservations expressed by managers on dividends, Fama and French (2001) note that the proportion of firms paying cash dividends has decreased drastically. This is the result of a lower propensity to pay dividends; this after controlling for determinants of dividends including profitability, investment opportunities, and firm size. According to the paper, one of reasons for the lower propensity to pay dividends is that the characteristics of publicly listed firms have tilted towards characteristics of firms that have never initiated a dividend - small, low earnings, and high investments. They also state that the perceived value

\footnotetext{
${ }^{1}$ Refer table 3 of Brav et.al. (2005)
} 
from paying dividends has also declined. Grullon and Michaely (2002) and Jagannathan, Stephens and Weisbach (2000) find that share repurchases have increased in prominence compared to dividends. Grullon and Michaely (2002) document that large, established firms have not decreased their dividend payouts, but they display a higher propensity to payout cash through shares repurchases. Together, these two papers find that increase in share repurchases can explain the decreasing propensity to pay dividends, which also corroborates the survey evidence in Brav et.al, (2005). However, none of these studies explicitly test the flexibility hypothesis. The flexibility offered by share repurchases could also be one of the reasons why firms choose to repurchase shares instead of paying dividends.

Flexibility in a firm's payout policy can be configured into three types - operational, reactive, and timing. Operational flexibility refers to the ability of firms to decide whether to distribute cash to shareholders or to keep it in the firm (e.g., for investments). Dividends and share repurchases may differ in their inherent operational flexibility. Instituting dividends may preclude firms from investing in profitable ventures if reducing dividends are met with adverse market reaction. As noted earlier, share repurchases may not suffer from this drawback.

In addition to operational flexibility, share repurchases accord firms with reactive flexibility. Reactive flexibility relates to the ability of repurchasers to evaluate the current and future environment, and alter an ongoing open market share repurchase program based on the dynamic changes in the environment. A dividend once announced is rarely reversed. On the contrary, a share repurchase announcement is not a firm commitment. Firms can decide to delay or even suspend an ongoing open market share repurchase program if the environment turns hostile. 
The final type of flexibility of share repurchases is the timing flexibility, which relates to the market timing of the actual open market repurchases. Timing flexibility accord managers the benefit of using their superior information to buy the stated amount of shares (or dollar value) when the market value of the shares drop below the intrinsic value of the firm. Research has already tested the timing flexibility and has found mixed evidence on the market timing ability of managers (Bozanic (2010); Cesari, Espenlaub, Khurshed and Simkovic (2010); Chan, Ikenberry and Lee (2007); Cook, Krigman and Leach (2004 )), hence we will not test the timing flexibility of share repurchases. In this paper we test the operational flexibility and reactive flexibility of share repurchases, which heretofore have not been tested. Specifically, we use the financial crisis period of 2008-2009 as a natural experiment to study operational and reactive flexibility associated with stock repurchases. To conduct our tests we classify firms into several predefined groups according to their payout policy: regular repurchasers, regular dividend payers, and occasional repurchasers.

In brief our findings are as follows. The proportion of regular repurchasing firms that reduced their payouts during the financial crisis is greater than the proportion of regular dividend paying firms that reduced their payouts. The stock price performance of regular repurchasing firms that did not announce repurchase plans (regular repurchasing firms that reduced their repurchase announcements) is better than the stock price performance of regular dividend paying firms that reduced their payouts. We also find that the amount spent on actual repurchases (actual number of shares repurchased) during the financial crisis is lower than those during period prior to the financial crisis.

Overall, the results support the flexibility theory. The regular repurchasing firms are flexible enough that a larger proportion of them were able to lower repurchase announcements. 
The market reaction to dividend reductions were more severe than the market reaction to reduction in repurchase announcements, which lends credence to the flexibility theory. The regular (and occasional repurchasing) firms were nimble enough that they reacted to the financial crisis by reducing their actual repurchases. Finally, the results indicate that the market does not differentiate between firms that completed their announced repurchase programs and firms that did not complete their announced repurchase programs.

The remainder of the paper is organized as follows. The next section presents the hypotheses. Section III describes the sample construction process. Section IV presents the data and empirical results and section $\mathrm{V}$ concludes.

\section{Hypothesis Development}

\section{A. Operational Flexibility}

Operational flexibility refers to the ability of a firm to alter its payout policy over time once the choice has been made to follow either a dividend paying or share repurchasing policy. Therefore, operational flexibility is a test of flexibility between dividend paying firms and repurchasing firms. As noted earlier, managers believe that dividends are regular and inflexible unlike share repurchases. Dividend payments induce an expectation of stable future dividends, and any reduction in dividends is met with an adverse market reaction. On the other hand, open market share repurchases by their very nature offer an element of flexibility. Open market repurchasers do not have the obligation to deliver on their announcements hence it is logical for a repurchaser to believe that open market share repurchase programs will not create an expectation of future repurchases. Further, the firm may also believe that any reduction in an open market repurchase program will not receive the same adverse market reaction as a dividend reduction. 
The challenge in testing the operational flexibility hypothesis is to examine a situation or event when this inherent operational flexibility between dividends and share repurchasers comes into play. The financial crisis of 2008-2009 provides such an opportunity. The financial crisis is an exogenous economic event that affected all firms. By examining how dividend payers and share repurchasers altered their payout policy in response to the financial crisis we should be able to shed light on the inherent operational flexibility between the two disbursement methods.

An effective test also requires that we compare otherwise similar firms. This suggests that regular dividend payers (RD firms) be compared to regular repurchasing (RR) firms rather than to all repurchasers. Research has found that the firm characteristics of RR firms are similar to RD firms. Jagannathan and Stephens (2003) find that frequent repurchasers are generally larger, have higher market-to-book ratios, and have lower volatility of operating income. Skinner (2008) on the other hand finds that firms that pay dividends regularly are large, mature, and profitable. Hence the comparison between RR firms and RD firms is a logical one. For testing the reactive flexibility we also consider the case of firms that are occasional repurchasers (OR). The classification of firms into RD, RR, OR firms will be detailed in section III.

It is well known that the financial crisis of 2008 - 2009 placed considerable pressure on the liquidity of firms throughout the economy. The onset of the financial crisis prompted many dividend payers to reduce dividends to conserve cash. Owing to the legacy of distributing dividends some dividend payers may have stayed away from reducing dividends. The perceived flexibility associated with repurchases suggests that to conserve cash during the financial crisis, RR firms may have more readily cutback on their repurchase programs. This part of the operational flexibility can be tested in two ways. First, if open market share repurchases are indeed flexible then we expect that RR firms to significantly curtail announcements of open 
market repurchase programs during the financial crisis period. Secondly, during the financial crisis period RR firms would have reduced the size of any announced open market repurchase programs compared to their pre-crisis average values.

If RR firms possess a level of flexibility that RD firms don't, then we expect the proportion of RR firms that reduced the number and size of open market share repurchase programs to be larger than the proportion of firms that reduced dividends ${ }^{2}$ among RD firms. We expect this to be so because not all dividend payers would have opted to reduce dividends owing to the rigidity of dividends, whereas far more RR firms would have instituted reductions in share repurchase announcements. On the other hand, if RR firms have become synonymous with RD firms we can expect them to be treated as RD firms. Consequently, the level of flexibility associated with RR firms will be limited and may even be non-existent. In this case, the proportion of RR firms that reduced open market share repurchase announcements will be similar to the proportion of dividend reduction announcements by RD firms. The reductions in share repurchase announcements can be measured in two ways: (1) the number of RR firms that did not announce a new open market share repurchase program during the financial crisis, and (2) the sum of the number of RR firms that did not announce a new open market share repurchase program and the number of RR firms that announced a lower repurchase value than the pre-crisis average values during the financial crisis period. More formally we can state our hypothesis as follows:

$H_{10}$ : During the financial crisis period, the proportion of $R R$ firms that reduced open market share repurchases (measured separately as firms that did not announce open market repurchase programs and as the sum of firms that did not announce and those that announced a

\footnotetext{
${ }^{2}$ Firms that reduced dividends - also includes those firms that omitted dividends.
} 
lower value than the pre-crisis average values) is similar to the proportion of firms among $R D$ firms that reduced dividends.

$H_{1 a}$ : During the financial crisis period, the proportion of $R R$ firms that reduced open market share repurchases (measured separately as firms that did not announce open market repurchase programs and as the sum of firms that did not announce and those that announced a lower value than the pre-crisis average values) is higher than the proportion of firms among $R D$ firms that reduced dividends.

Operational flexibility is predicated on the belief that shareholders do not penalize firms that reduce share repurchases compared to firms that reduce dividend. There is ample evidence to show that dividend payers suffer negative market reaction upon dividend reduction or dividend omission announcement (Christie (1994); Healy and Palepu (1988); Liu, Szewczyk and Zantout (2008); Sant and Cowan (1994 )). On the other hand, firms may not suffer a negative market reaction if there is any reduction in share repurchases, which may be a flexibility offered by share repurchases over dividends. However, this has yet to be documented and which we hope to test here. The difficulty in constructing the test is that unlike dividends there are no explicit announcements by RR firms that they will not be undertaking or omitting a repurchase program in a given period. We can only infer from the absence of an open market repurchase announcement in a given period of time that the firm has chosen to deliberately alter its regular payout plan. With reference to our focus on the financial crisis period, we assume that the lack of any announcements of repurchase program by RR firms during the crisis period is analogous to a dividend omission by an RD firm. If operational flexibility holds then we expect to see that the adverse market reactions to the absence of share repurchase announcements, if any, should be lower than the adverse market reactions to dividend reductions. Ideally we would want to 
compare the market reaction of dividend omitters to share repurchase omitters. However, many RD firms chose to reduce the dividend to a very abnormal level without omitting dividends altogether. Consequently, we have chosen to compare the market performance of repurchase omitting RR firms to dividend reducing RD firms including those omitting the dividends altogether. This test should be conservative since we are comparing repurchase omitting firms to a set of RD firms that includes dividends omitters and reducers. Despite this expanded sample of $\mathrm{RD}$ firms if we find that the stock price performance of RR firms that did not announce repurchases was better than the stock price performance of RD firms that reduced dividends then we can be more confident that operational flexibility holds. More formally this hypothesis may be stated as follows -

$H_{20}$ : During the financial crisis period, stock performance of RR firms that did not announce open market repurchase programs will be similar to the stock performance RD firms that reduced dividends.

$H_{2 a}$ : During the financial crisis period, stock performance of RR firms that did not announce open market repurchase programs will be better than the stock performance RD firms that reduced dividends.

Rather than omitting repurchases altogether, it is conceivable that RR firms during the financial crisis period choose to announce scaled back repurchase program compared to their pre crisis levels. We can interpret the reduction in the value of open market share repurchase announcements as evidence of operational flexibility if their stock performance is better than the stock performance of RD firms that reduced dividends.

This leads to our next hypothesis: 
$H_{30}$ : During the financial crisis period, stock performance of RR firms that announced lower repurchases value than their pre-crisis average will be similar to stock performance of $R D$ firms that reduced dividends.

$H_{3 a}$ : During the financial crisis period, stock performance of $R R$ firms that announced lower repurchase values than their pre-crisis average will be better than stock performance of $R D$ firms that reduced dividends.

\section{B. Reactive Flexibility}

Reactive flexibility refers to the ability of repurchasers to address dynamic conditions and alter their payout policy once they are announced. The tests will be based on the behaviors of OR and RR firms. In comparison to OR firms, we are particularly keen to examine whether RR firms still retain the flexibility to alter their payout policy in response to changing conditions because the latter are presumed to behave like RD firms.

The financial crisis of 2008-2009 provides a natural setting to test the reactive flexibility of repurchases. The severity of the crisis suggests that it may elicit drastic changes to an ongoing open market share repurchase program. Reactive flexibility was defined earlier as the ability to modify an ongoing open market share repurchase program. After the onset of financial crisis, if repurchasers delayed the ongoing open market repurchases programs, then we should expect a decrease in the amount spent on share repurchases and a decrease in the total number of shares repurchased. In formal terms this may be presented as:

$H_{40}$ : During the financial crisis period, the amount spent on share repurchases (number of shares repurchased) relative to the announced program by $R R(O R)$ firms was similar to the amount spent on share repurchases (number of shares repurchased) relative to the announced program by RR (OR) firms prior to the financial crisis period. 
$H_{4 a}$ : During the financial crisis period, the amount spent on share repurchases (number of shares repurchased) relative to the announced program by $O R(R R)$ firms was lower than the amount spent on share repurchases (number of shares repurchased) relative to the announced program by OR (RR) firms prior to the financial crisis.

Reactive flexibility also implies that alterations to an existing plan may not be penalized by the market. Therefore, markets should be indifferent to firms that repurchased shares according to their ongoing open market share repurchase programs as opposed to firms that did not repurchase shares according to their ongoing open market share repurchase programs. In other words, we do not expect to reject the following null hypothesis.

$H_{50}$ : During the financial crisis, stock market performance for $R R(O R)$ firms that completed open market share repurchase programs was similar to the stock market performance for $R R(O R)$ firms that did not complete their open market share repurchase programs.

$H_{5 a}$ : During the financial crisis, stock market performance for $R R(O R)$ firms that completed open market share repurchase programs was better than the stock market performance for $R R(O R)$ firms that did not complete their open market share repurchase programs.

\section{Sample Construction}

This section details the selection of the sample period and the classification of firms into different categories such as RD firms, RR firms, OR firms.

\section{A. Study Period}

The overall period of study can be split into the firm classification period, pre-crisis period, and financial crisis period. We first start by identifying the financial crisis period and then work backward to include the pre-crisis period and the classification period. As mentioned 
during hypothesis development, the financial crisis period plays a pivotal role in our ability to test the flexibility hypothesis. It is important to identify the starting and the ending points of the financial crisis because the ensuing payout policy of firms will be drastically affected by those time points. When fears of the crisis solidified, firms may have reacted by implementing payout cuts and, conversely, when the crisis eased its grip, firms may have resumed their payouts. Observations before the starting point of the financial crisis will be classified as the pre-crisis period and the period between the starting point and the ending point of the financial crisis will constitute the financial crisis period. For testing purposes we identify a pre-crisis 'normal' period against which the behavior during the financial crisis period is assessed. We define years 2006 and 2007 as the pre-crisis period. Finally, we identify a classification period that pre-dates the pre-crisis period of 2006 - 2007. The classification period starts in 1984 and ends in 2005. We employ a classification scheme during the classification period to classify firms into RR, RD, and OR firms.

Next, we discuss details about the construction of each of these sub-periods. Determining the financial crisis period is very crucial for the accuracy of the study. Inaccurate starting and ending points have the potential to adversely affect the conclusions of our study because we are using the financial crisis as the trigger that affected payout behavior of firms depending upon the presumed flexibility of their payout policies. An incorrect financial crisis period identification, for obvious reasons, may lead to the wrong conclusions. To identify the starting point and the ending point of the financial crisis we turn to three sources - the financial crisis timeline published by the St. Louis Federal Reserve Bank, the business cycle data published by the National Bureau of Economic Research (NBER), and the levels of the Dow Jones Industrial Average (DJIA) Index. 
First, let us explain how we identified the starting point and ending point of the financial crisis using the financial crisis timeline published by the St. Louis Fed. The Financial Crisis Inquiry Commission (FCIC) in its report(Angelides (2011 )) tabled on January 27, 2011 refers to early 2007 as the time period that provided initial indications of impending trouble. The findings of the FCIC are supported by the financial crisis time published by the St. Louis Fed. According to the St. Louis Fed, the timeline of events starts in early $2007^{3}$. However, it was not until the end of the second quarter of 2007 that events portending a calamitous future began to unfold. Based on the news events in the fourth quarter of 2009 and the first quarter of 2010 we could assert that the fear of the crisis receded during the fourth quarter of 2009, which marks the ending point of the financial crisis ${ }^{4}$. Our second source to identify the starting point and the ending point of the financial crisis is the business cycle data published by the NBER. According to the NBER the peak in economic activity appeared in December 2007 and the trough in economic activity appeared in June 2009 capping the recessionary trend. Finally, we also rely on the market's assessment of the starting and ending points of the financial crisis by examining the levels of the DJIA. The peak in the DJIA appeared on October 9, 2007, following which the DJIA index embarked on a long downtrend. The trough in the DJIA appeared on March 9, 2009 reversing the downtrend. A summary of the starting and ending point of the financial crisis using the three different methods is provided in appendix 1. Based on appendix 1, as well as to keep the analysis simple, we designate the starting point and the ending point of the financial crisis as the first quarter of 2008 and the ending point as the last quarter of 2009, which in essence constitute the years 2008 and 2009.

\footnotetext{
${ }^{3}$ The timeline of events and policy actions pertaining to the financial crisis can be accessed from http://timeline.stlouisfed.org/

${ }^{4}$ The Volatility index (VIX) monthly and quarterly averages also corroborates the starting and ending point of the financial crisis identified using the financial crisis timeline report by the St. Louis Fed.
} 
We define the pre-crisis test period as the years of 2006 and 2007. The pre-crisis test period is used as a benchmark period to assess how the financial crisis affected the payout behavior of firms. The payout behavior of firms during 2006 and 2007 is expected to be the standard given normal economic circumstances.

Finally, the classification period refers to the sample time period used categorize firms into the various payout types: RD, RR, and OR firms. The classification time period extends from 1984 to 2005. The next section develops our classification methodology in much detail.

\section{B. Classification of Firms}

Proper classification of firms into different payout categories (RD firms, RR firms, and OR firms) is of considerable importance in our quest to test the flexibility hypothesis. Misclassification of firms also has the potential to adversely influence the conclusions of this study. Our classification algorithm uses Skinner's (2008) methodology as a starting point but modifies it considerably to accommodate its short comings. The substitution of dividends with share repurchases is the main hypothesis of Skinner (2008). To test the hypotheses, Skinner classifies firms into different groups such as regular dividend payers, regular repurchasers and occasional repurchasers based on the payout policy of firms during $1980-2005$. One of the contributions of Skinner (2008) is the identification of the emergence of distinct group of payers. These groups consist of firms that pay only dividends, firms that only repurchase shares, and so on. Firms that regularly pay dividends were defined as firms that made no repurchases but paid dividends for at least 6 years. Firms that make regular repurchases were defined as firms that paid no dividends but made repurchases in at least 6 years. Firms that occasionally make repurchases were defined as firms that paid no dividend but made repurchases up to a maximum of 5 years. 
Though Skinner’s methodology can be adopted for our study, it is subject to two major shortcomings. Firstly, the adoption of the Skinner (2008) methodology will preclude firms that have occasionally paid dividends and occasionally repurchased shares, and firms that have regularly paid dividends and regularly repurchased shares. For example, out of the 10,675 firms considered, 3,367 (which is 31\% of the sample) firms are not classified into any group. Within these 3,367 firms, firms that have paid dividends in at least six years and repurchased shares in less than 11 years constitute 1,157 firms, and firms that repurchased shares in at least six years and paid dividends in less than 11 years constitute 413 firms. Both these categories make up a significant portion of the sample of firms. Secondly, this schema does not consider the most recent payout behavior of firms. For example, let us consider three firms - A, B and C that have paid dividends for at least 5 years. Suppose firm A paid dividends in 1980, 1985, 1990, 1995, and 2000. Suppose firm B has paid dividends from 1980 through 1984 and none thereafter. Let us suppose that firm C has paid dividends from 1998 through 2003. It is appropriate to classify firm $\mathrm{C}$ as a regular dividend payer than to classify firm $\mathrm{A}$ or $\mathrm{B}$ as a regular dividend payer, which according to Skinner (2008) would not have qualified as an RD firm.

To rectify the shortcomings of Skinner's (2008) schema, we evaluate the payout behavior of firms between $1984^{5}$ and 2005 and devise a modified set of heuristic rules to classify firms into different categories that accommodates for the fact that some firms pay dividends as well as repurchase shares, and gives greater emphasis to the recent payout behavior of firms. Barring this relaxation we would have excluded a large number of firms from our sample and would have incorrectly classified firms into different categories. To begin with, we devise the payout choice (PC) ratio, which is defined as the dollar amount distributed through dividends divided by the

\footnotetext{
${ }^{5}$ It was not until 1982 that SEC instated rule 10b - 18 that provided a safe harbor for firms that repurchased shares.. After 1982 repurchases became a significant portion of the firm payouts. Moreover, SDC started compiling share repurchase data only from 1984. Therefore, our classification period starts from 1984.
} 
dollar amount of shares repurchased in a given year. The PC ratio also acknowledges the fact that firms pay dividends as well as repurchase shares. A firm could still be categorized as a dividend payer if the majority of the payouts are distributed through dividends. By using the PC ratio we aim to capture any recent changes in the payout nature of the firms particularly any trends related to the substitution effect.

$$
P C_{i, t}=\frac{\text { Dividends }_{i, t}}{\text { Share Repurchases } s_{i, t}}
$$

The proponents of the substitution hypothesis have found that dividends are being substituted by share repurchases. In other words, a regular dividend paying firm could have altered its payout strategy over time to favor share repurchases as the chosen method to distribute cash. To acknowledge the substitution hypothesis, the payout mix, and to place significance on the most recent payout behavior we define RD, RR and OR firms as follows. A firms is classified as a RD firm if it meets the following conditions -

RD Condition 1 - Distributed dividends for at least 5 years during $1984-2005$ period.

RD Condition 2 - Distributed dividends for at least 2 years during 1999 - 2005 period.

RD Condition 3 - Average PC ratio for the last three payouts should be greater than 1 . A firm is classified as a RR firm if it meets the following conditions -

RR Condition 1 - Announced repurchases for at least 5 years during 1984 - 2005 period.

RR Condition 2 - Announced repurchases for at least 2 years during 1999 - 2005 period.

RR Condition 3 - Average PC ratio for the last three payouts should be less than 1 . If a firm fails to meet condition RR2 but meets condition RR1 and RR3 then the firm is classified as an OR firm.

Additionally, a firm is classified as an OR firm if it meets the following conditions - 
OR Condition 1. Announced repurchases up to a maximum of 4 years during $1984-2005$ period.

OR Condition 2. Average PC ratio for those payouts should be less than 1.

The data sources and empirical methodologies adopted to test the operational and reactive flexibility and the results obtained thereof are detailed in the following section.

A. Data

\section{Data and Empirical Methodology}

The requisite data for our study is collected from multiple sources. For classification purposes we need data on the number of times a firm distributed dividends, the number of times a firm repurchased shares, and the annual ratio of the amount distributed through dividends to the amount spent on share repurchases; we collect the dividend information from CRSP and share repurchases data from COMPUSTAT.

The first hypothesis includes a comparison of the ratio of $\mathrm{RD}$ firms that reduced dividends to the ratio of RR firms that did not announce share repurchases, and to the ratio of RR firms that announced lower share repurchase amounts. The second (third) hypothesis is the comparison of stock price performance during the financial crisis period of RD firms that reduced dividends during the financial crisis to the stock price performance of RR firms that did not announce repurchases (announced lower repurchase amounts) during the financial crisis. The first three hypotheses require data on dividends distributed and share repurchase announcement amounts. Dividend data for the first three hypotheses is collected from CRSP and the share repurchase announcement amounts data is collected from SDC Platinum. The missing repurchase announcements in the SDC Platinum database were identified and added to the sample by searching through the 8-K filings. 
Hypothesis four compares the actual amount spent on share repurchase (actual number of shares repurchased) by RR and OR firms during the financial crisis period to those prior to the financial crisis period. Hypothesis five compares the stock price performance during the financial crisis period of RR firms (and OR firms) that completed their share repurchase programs announced during the financial crisis to those that did not complete their share repurchase programs announced during the financial crisis. To test hypothesis four and five we need data on actual share repurchases. Previous studies mostly relied on the COMPUSTAT or CRSP data to identify actual share repurchases in any given period. Banyi, Dyl and Kahle (2008) prove that most of the prevalent methods which rely on COMPUSTAT and CRSP data (Fama and French (2001); Grullon and Michaely (2002); Kahle (2002); Stephens and Weisbach (1998 )) display high error rates ${ }^{6}$. These studies however did not have any choice as firms did not have to disclose actual repurchases of stock in their financial statements. This situation changed with the revisions made in 2003 to the Securities Exchange Act 1934 mandating firms to disclose all shares repurchase activity in their quarterly and annual reports. To avoid the errors and possible biases in estimating the actual share repurchased, we also hand collect data from the 10Q reports using Direct Edgar ${ }^{7}$.

\section{B. Summary Statistics}

Table I provides the summary statistics. By median size, RD firms are larger than RR firms, which in turn are much larger than OR firms. The median cash ratio for all three types of firms is in excess of 7\% and OR firms carry the highest cash. OR firms are much smaller and

\footnotetext{
${ }^{6}$ Banyi et.al (2008) provide a compilation of methods used by researchers to estimate share repurchases and state that most methods to estimate actual share repurchased display high error rates of at least $30 \%$ and these methods underestimate the actual repurchases for firms that include a high proportion of option compensation.

${ }^{7}$ Bozanic (2010) also hand collected the actual repurchases during 2004 - 2006 period from 10-Q filings.
} 
could be facing volatile cash flows, which may account for their high cash ratio. RD firms have the highest leverage followed by RR firms and then by OR firms. All three types of firms spend more than $2 \%$ of their total assets on capital expenditures. Measured by the median ROA, RR firms appear to be most profitable followed by RD firms and by OR firms. Measured by median $R O E$, RD firms appears to be most profitable followed by RR firms and by OR firms. The median Market-to-book (MB) ratio is highest for RR firms followed closely by RD firms and then by OR firms.

[Insert Table I about here]

\section{Empirical Methodology and Results}

This sub-section presents the empirical methodologies and results for each of the hypotheses. Hypotheses one through three provide tests of operational flexibility and hypotheses four and five provide tests of reactive flexibility.

\section{C.1. Hypothesis One}

Hypothesis one tests whether the proportion RR firms that reduced payouts during the financial crisis period are greater than the proportion of RD firms that reduced payouts during the financial crisis period. RR firms that reduced repurchases are measured in two ways. The first measure considers only cases where the firms did not announce any open market repurchase programs during the financial crisis period while the second measure considers both firms that did not announce any repurchase programs plus firms that announced repurchases but at a lower repurchase amount than their pre-crisis levels. In the case of $\mathrm{RD}$ firms, the number of $\mathrm{RD}$ firms that reduced dividends includes firms that omitted dividends plus the firms that announced a 
lower dividend than their pre-crisis levels. The test consists of comparing the proportions for the $\mathrm{RD}$ and RR firms by way of a Chi-square test.

Table II provides the results of our first hypothesis. There are $641 \mathrm{RD}$ firms that paid at least one dividend during the pre-crisis period, and $433 \mathrm{RR}$ firms that announced at least one repurchase program during the pre-crisis period. Out of these 641 RD firms, 322 firms reduced dividends in both 2008 and 2009. The reduction in this case was measured as crisis average dividend minus pre-crisis average dividend. Out of 641 RD firms, 370 firms reduced dividends in either 2008 and (or) 2009. The reduction in this case was measured as yearly dividend during the crisis minus the pre-crisis average dividend. Out of the 433 RR firms, 232 firms did not announce a repurchase program in both 2008 and 2009, and 386 firms did not announce a repurchase program in either 2008 and (or) 2009. We also tabulate cases where RR firms continued to announce new repurchase programs during the financial crisis period but at lower levels than their pre-crisis average amounts. Out of the 433 RR firms, 376 firms announced a lower repurchase program in both 2008 and 2009. In this case the reduction was measured as crisis average announcement value minus the pre-crisis average announcement value 415 firms announced a lower repurchase program in either 2008 and (or) 2009. In this case, the reduction was measured as yearly announcement value minus the pre-crisis average announcement value.. We find that the ratio of RD firms that reduced dividends in both 2008 and 2009 (50.23\%) is not statistically different from the ratio of RR firms that did not announce a repurchase program in 2008 and 2009 (53.57\%). The ratio of RR firms that did not announce a repurchase program in either 2008 and (or) 2009 (89.15\%) is statistically greater than the number of RD firms that reduced dividends in either 2008 and (or) 2009 (73.32\%), which supports our hypothesis that RR firms are more aggressive than RD firms in cutting back on payouts. The ratio of RR firms that 
announced a lower value for their repurchase program in 2008 and 2009 (86.83\%) is statistically greater than the ratio of RD firms that reduced dividends in 2008 and 2009 (50.23\%). The ratio of RR firms that announced a lower value for their repurchase program in either 2008 and/or 2009 (95.84\%) is statistically greater than the ratio of $\mathrm{RD}$ firms that reduced dividends in either 2008 and (or) 2009 (73.32\%). All except one comparison provide robust support that RR firms were operationally more flexible than RD firms.

[Insert Table II about here]

\section{C.2. Hypothesis Two}

Our second hypothesis tests whether the stock performance following lack of open market share repurchase announcements during the financial crisis was better than the stock price performance following dividend reduction announcements during the financial crisis. We use the standard single index model event study methodology using EVENTUS to test our second hypothesis where the event period encompasses the entire financial crisis period. The CRSP value-weighted index is used as market portfolio. The estimation period comprises of 250 days beginning 315 days prior to the start of the financial crisis period and ending 65 days prior to the start of the financial crisis period. Daily abnormal returns are aggregated over the event window to obtain the cumulative abnormal returns (CARs). Where CAR is the cumulative abnormal return over the financial crisis event window. The event window $(0,+500)$ is 500 trading days after Jan 1, 2008, which would roughly equate with the years 2008 and 2009.

We then compare the CARs for the RR firms that did not announce repurchases during the financial crisis period to the CARs for RD firms that reduced dividends during the same period. For this purpose we use the t-test, Wilcoxon's median test, and Kolmogorov-Smirnov test. In addition we also conduct multiple regression tests with the CARs as the dependent 
variable and a dummy variable to indicate a firm that reduced dividends or a firm that reduced repurchases plus control variables for payout reduction and firm size.

$C A R_{i}=\alpha_{i}+\delta D_{i}+\beta_{1}$ PayoutReduction $+\beta_{2}$ Size

$D_{i}$ is a dummy variable that takes values of 1 if the firm is a RD firm that reduced dividends and 0 if it is a RR firm that reduced its repurchases during the event window. To control for the magnitude of the payout reduction we include PAYOUT REDUCTION, which is measured as average payout during the crisis period minus the average payout during the pre-crisis period. Firm size is an important determinant of payouts. Therefore, to control for firm size we include SIZE, which is measured as the log of total sales.

Table III - Panel A shows that the mean (median) CAR for RR firms that did not announce any repurchase program during both the years (2008 \& 2009) of the financial crisis period is $0.5579 \%(0.4663 \%)$ and the mean (median) CAR for RD firms that reduced their dividends during both the years (2008 \& 2009) of the financial crisis period is $0.2094 \%$ (0.1379\%). The dividend reduction by an RD firm is measured as the crisis-period average dividend minus pre-crisis period average dividend. The t-test, Wilcoxon test, and the Kolmogorov-Smirnov test support the operational flexibility hypothesis that RD firms that reduced dividends during the financial crisis period were penalized more than RR firms that did not announce a repurchase program during the financial crisis period. Panel B shows mean (median) CAR for RR firms that did not announce a repurchase program during either of the years (2008 and/or 2009) of the financial crisis is $0.4376 \%$ (0.3596\%), and the mean (median) CAR for RD firms that reduced dividends during either of the years (2008 and/or 2009) of the financial crisis period is $0.2250 \%(0.1822 \%)$. The reduction in dividends by a RD firm is measured as the yearly dividend during the crisis period minus the pre-crisis average dividend. 
The t-test, the Wilcoxon test, and the Kolmogorov-Smirnov test are statistically significant, providing further support for the operational flexibility theory. Results from Panel C further bolster the operational flexibility theory. The dummy variable $R D$ is negative and statistically significant in all models, which suggests that the CARs for RD firms that have reduced dividends are lower than the CARs for RR firms that did not announce repurchase programs.

[Insert Table III about here]

\section{C.3. Hypothesis Three}

Hypothesis three is analogous to hypothesis two but examines the stock performance of RR firms that reduced their share repurchase announcement values during the financial crisis period and compares these to the stock performance of $\mathrm{RD}$ firms that reduced dividends during the financial crisis period. Table IV - Panel A shows mean (median) CARs for RR firms that announced a lower share repurchase value during both the years (2008 \& 2009) of the financial crisis period is $0.4699 \%(0.4508 \%)$. The reduction in share repurchase announcement values is measured as the average share repurchase announcement values during the financial crisis period minus the average share repurchase announcement values prior to the financial crisis period. The mean (median) CAR for RD firms that reduced dividends during both the years (2008 \& 2009) of the financial crisis period is $0.2094 \%(0.1379 \%)$. The dividend reduction by an RD firm is measured as the crisis-period average dividend minus pre-crisis period average dividend. The ttest, Wilcoxon test, and the Kolmogorov-Smirnov test reveal that the CARs for RD firms that reduced payouts during the financial crisis were significantly lower than the CARs for RR firms that reduced payouts during the financial crisis period. Panel B shows that mean (median) CAR for RR firms that reduced share repurchase announcement values during either of the years (2008 and/or 2009) of the financial crisis period is $0.3299 \%(0.2610 \%)$. The reduction in share 
repurchases is measured as the yearly share repurchase announcement values minus the yearly average pre-crisis announcement values. The mean (median) CAR for RD firms, that reduced dividends during either of the years (2008 and/or 2009) of the financial crisis period, is $0.2250 \%$ (0.1822\%). The reduction in dividends by a RD firm is measured as the yearly dividend during the crisis period minus the pre-crisis average dividend. The t-test, Wilcoxon test, and the Kolmogorov-Smirnov test are statistically significant, which shows that the CARs for RD firms that reduced payouts during the financial crisis were much less than the CARs for RR firms that reduced payouts during the financial crisis. The results from Panels A and B confirm our expectations for hypothesis three that the stock market performance of RD firms that reduced dividends during the financial crisis was lower than the stock market performance of RR firms that announced a lower repurchase value during the financial crisis period. Results from Panel C further support the operational flexibility theory. The dummy variable RD is negative and statistically significant in all the models, which suggests that the CARs for RD firms that have reduced dividends are lower than the CARs for RR firms that reduced their repurchase announcement values.

\section{[Insert Table IV about here]}

Overall, we find that there is support for the operational flexibility hypothesis. We find that the proportion of RR firms that did not announce repurchases is higher than the proportion of RD firms that reduced dividends during the financial crisis period. Consistent with operational flexibility we further find that the CARs of RR firms that did not announce repurchases (that announced lower repurchases amounts) are higher than the CARs of RD firms that reduced dividends during the financial crisis period. 


\section{C.4. Hypothesis Four}

We hypothesize that the amount spent on actual ${ }^{8}$ share repurchases (number of actual shares repurchased) by RR (OR) firms during the financial crisis will be lower than the amount spent on actual share repurchases (number of actual shares repurchased) by RR (OR) firms before the financial crisis. RR (OR) firms that did not announce a repurchase program in 2008 \& 2009 were also added to this sample and they had a value of zero for amount spent on share repurchases (and for the number of shares repurchased). The amount spent on repurchases was scaled by total assets. We scaled the number of shares repurchased by the number of shares sought during the announcement of the open market share repurchase program. This hypothesis will be tested using the t-test, Wilcoxon's test, and the Kolmogorov-Smirnov test for the equality of distribution. We perform the analysis by year instead of by program for the following reason. In lieu of the financial crisis firms could have lowered their repurchase announcement values and could have spent lower amounts on actual share repurchases. In table II we showed that at least 85\% of the RR firms lowered their announcement values during the financial crisis compared to their pre-crisis announcement values. Therefore, if we compute the maximum of the amount spent on actual repurchases (actual share repurchased) by program we might find that firms had false higher maximum. Moreover, a yearly comparison provides a common unit of reference.

Table V-A ${ }^{9}$ presents the results of our fourth hypothesis using the amount spent on repurchases scaled by total assets. Panel A and B provide the results for RR and OR. The mean

\footnotetext{
8 “Actual” refers to the information collected directly from the 10-q and 10-k reports rather than from COMPUSTAT.

${ }^{9}$ We also tested hypothesis four by including only those firms that announced a repurchase program during the financial crisis and prior to the financial crisis. The results were similar.
} 
(median) of the maximum amount spent by RR firms prior to the financial crisis was $10.29 \%$ of total assets (7.32\% of total assets) and during the financial crisis were $8.29 \%$ of total assets (4.28\% of total assets). The mean (median) of the maximum amount spent by OR firms prior to the financial crisis was $8.92 \%$ of total assets (6.51\% of total assets) and during the financial crisis was $6.39 \%$ of total assets (2.64\% of total assets). Appendix 2 provides an illustration for the calculation of the maximum. For all the panels, t-test, Wilcoxon test and the Kolmogorov Smirnov test suggest that the amount spent on repurchases by RR (OR) firms during crisis was lower than the amount spent on repurchases by RR (OR) firms prior to the financial crisis.

[Insert table V A about here]

Table V-B presents the results of our fourth hypothesis using the number of shares repurchased in each program scaled by the total number of shares sought in each program. Panel A and B provide the results for RR and OR firms. The mean (median) of the maximum fraction of shares repurchased by RR firms prior to the financial crisis was $90.11 \%$ of the shares sought at announcement (86.58\% of the shares sought at announcement) and during the financial crisis was $69.92 \%$ of the shares sought at announcement $(58.29 \%$ of the shares sought at announcement). The mean (median) of the maximum fraction of shares repurchased by OR firms prior to the financial crisis was $75.04 \%$ of the shares sought at announcement (67.92\% of the shares sought at announcement) and during the financial crisis was $51.48 \%$ of the shares sought at announcement (32.89\% of the shares sought at announcement). For both the panels, the t-test, Wilcoxon test and the Kolmogorov Smirnov test suggest that the maximum fraction of the number of shares repurchased by RR (OR) firms during crisis was lower than the maximum fraction of the number of shares repurchased by RR (OR) firms prior to the financial crisis.

[Insert table V B about here] 


\section{C.5. Hypothesis Five}

If the market places a premium on actual repurchases, then during the financial crisis period the stock performance of RR (OR) firms that completed their ongoing open market share repurchase programs should be better than the stock performance of RR (OR) firms that did not complete their ongoing open market repurchase programs during the financial crisis. Contrarily, if reactive flexibility theory holds, then we expect that the market should not differentiate between those firms that completed their repurchase programs and those firms that did not complete their repurchase programs. We will utilize the observation during the financial crisis as our sample period to test this hypothesis. Hypothesis five examines whether such a premium exists or not. We will test hypothesis six in a similar manner to how we tested hypothesis two and three. First, we will test the equality in CARs using the t-test, the Wilcoxon's test, and the Kolmogorov-Smirnov test. Second, we will also use equation (2) with some modifications to explain the variation in CARs. Equation (3) will be used to explain the CARs for RR firms and equation (4) will be used to explain the CARs for OR firms.

$C A R_{i}=\alpha_{i}+\delta D_{i}+\beta_{i}$ Size

$C A R_{i}=\alpha_{i}+\delta H_{i}+\beta_{i}$ Size

where $D_{i}$ is a dummy variable that takes the value of 1 if an RR firm completed all open market share repurchase programs during the financial crisis, and 0 otherwise. $H_{i}$ is a dummy variable that takes the value of 1 if an OR firm completed all open market share repurchase program during the financial crisis, and 0 otherwise. If the market places a premium on actual repurchases during the financial crisis, then we expect the dummy variables $D_{i}$ and $H_{i}$ to be 
statistically significant and positively related to CARs. On the other hand, if reactive flexibility holds, then we expect the dummy variables to be not significant.

Table VI presents the results of the fifth hypothesis. Of the RR firms, $43 \%$ actually completed all their repurchase programs during the financial crisis. The mean (median) CAR for RR firms that did complete their repurchase programs during the financial crisis is $0.3090 \%$ (0.2643\%) and the mean (median) CAR for RR firms that did not complete their repurchase programs during the financial crisis is $0.2791 \%(0.2277 \%)$. Of the OR firms, $45 \%$ of the firms actually completed all their repurchase programs during the financial crisis. The mean (median) CAR for OR firms that did complete their repurchase programs during the financial crisis is 0.3370\% (0.3310\%) and the mean (median) CAR for OR firms that did not complete their repurchase programs during the financial crisis is $0.1722 \%(0.1873 \%)$. None of the statistical tests were significant. Panel C - models 1 and 2 provide the regression results of CARs of RR firms. Panel $\mathrm{C}$ - models 3 and 4 provide the regression results of CARs of OR firms. The dummy variable COMPLETE, is not statistically significant in any of the models. The results from Table VI suggest that the market does not differentiate a firm that completed its repurchase program from a firm that did not complete its repurchase program, which strongly supports the reactive flexibility hypothesis.

\section{[Insert Table VI about here]}

Overall, we find that there is robust support for reactive flexibility hypothesis. Table V-A presented the results of our fourth hypothesis where we expect that the amount spent on repurchases by firms during the financial crisis to be lower than the amount spent on repurchases by firms prior to the financial crisis. Table V-B presented the results of our fourth hypothesis where we expect that the number of shares repurchased by firms during the financial crisis to be 
lower than the number of shares repurchased by firms prior to the financial crisis. We find that results from V-A \& V-B support our expectation that the amount spent on repurchases (the number of shares repurchased) during the financial crisis is lower than the amount spent on repurchases (the number of shares repurchased) prior to the financial crisis. Table VI presented the results of our fifth hypothesis where we expect that the CARs of RR (OR) firms that completed the repurchase program not to be different from the CARs of RR (OR) firms that did not complete the repurchase program. Results from table VI show that not more than $45 \%$ of the firms actually completed all their repurchase programs during the financial crisis. We also found that the CARs are not statistically different from each other. The regression results also show that the market does not favor a firm that completed its repurchase program than a firm that did not complete its repurchase program. The results from our fourth and fifth hypothesis overwhelmingly support the reactive flexibility hypothesis.

\section{Conclusions}

Fama and French published their paper on dividend substitution in 2001. Since then several papers have explored the issue of substitutability between dividends and share repurchases (Grullon and Michaely (2002); Jagannathan, Stephens and Weisbach (2000)). Researchers have argued that the apparent flexibility of share repurchases motivates firms to payout a larger fraction of their overall payouts in the form of share repurchases than through dividends. The focus of these papers has largely been on what we term as operational flexibility. In addition to operational flexibility, we identify two other types of flexibilities associated with repurchases: reactive and timing flexibility. In this paper we examine both operational and reactive flexibility of repurchases. 
Operational flexibility refers to the ability of firms to decide whether to distribute cash to shareholders or to keep it in the firm (e.g., for investments). Dividends and share repurchases may differ in their inherent operational flexibility. Instituting dividends may preclude firms from investing in profitable ventures if reducing dividends are met with adverse market reaction. As noted earlier, share repurchases may not suffer from this drawback. Reactive flexibility relates to the ability of repurchasers to evaluate the current and future environment, and alter an ongoing open market share repurchase program based on the dynamic changes in the environment. A dividend once announced is rarely reversed. On the contrary, a share repurchase announcement is not a firm commitment. Firms can decide to delay or even suspend an ongoing open market share repurchase program if the environment turns hostile.

The financial crisis of 2008 and 2009 was an event with profound implications not only for the US economy but also for the global economy. It is a well-known and documented fact that many firms reduced payouts in response to the financial crisis. We use the financial crisis as an event to test the flexibility theory at the operational level and in a reactive sense. Hypotheses one through three explore the concept of operational flexibility. We examine whether regular share repurchasers were more flexible than regular dividend payers during the financial crisis. Hypotheses four through six explore the concept of reactive flexibility, whereby we examine the ability of regular repurchasers and occasional repurchasers to alter their payout policy during the financial crisis.

To perform our analysis we need a sound classification system to categorize firms into different groups such as regular dividend payers, regular repurchasers, and occasional repurchasers. We rely on the Skinner (2008) classification system to categorize firms. However, in section IV we have identified some flaws associated with the Skinner classification system; 
hence we propose a new classification system, one that modifies the Skinner classification to rectify some of the shortcomings.

Survey evidence suggests that dividends are considered to be rigid. A firm that pays dividends is expected to pay (increase) the dividends in future or face adverse market reaction if it opts to reduce dividends. Therefore, once a firm starts paying dividends it becomes constrained by its choice. This choice to pay dividends may preclude the firm from investing in profitable ventures or conserving cash for future needs. Fearing adverse market reaction the dividend paying firms might opt not to reduce dividends whereas a repurchasing firm might not feel as constrained as a dividend paying firm and might decide freely to reduce repurchases. Since there were numerous reports in the business press during the financial crisis that payouts have almost disappeared, in our first hypothesis we set to explore which category of firms responded by reducing their payouts. We find that the regular repurchasers were aggressive in reducing payouts than were regular dividend payers, which provides supports for the operational flexibility theory. In our second and third hypothesis we aim to examine the stock market performance of regular dividends payers that reduced dividends during the financial crisis and the stock market performance of regular repurchasers that reduced repurchases. We find that the market reaction to dividend reductions is worse than the market reaction to regular repurchasing firms that reduce repurchases. The stock market performances of RD firms that reduced dividends is found to be lower than the stock market performances of RR firms that reduced repurchases. Our analysis supports operational flexibility, and proves that firms might feel restricted due to the choice to pay dividends than to repurchase shares and they may not reduce dividends as much as reducing repurchases. 
Hypothesis four and five address the reactive flexibility of repurchases. We compare the behavior of regular (occasional) repurchasers prior to the financial crisis and during the financial crisis. In hypothesis four we compare the maximum amount spent on share repurchases scaled by total assets (the maximum number of shares repurchased scaled by the number of shares sought at the announcement) by regular repurchaser during the financial crisis to those of pre-crisis values. We find strong evidence that repurchasers spent less on actual repurchases (actually repurchased lower fraction of shares) during the financial crisis than during the pre-crisis period. Hypothesis five examines whether the stock market differentiates the repurchasers that completed their repurchase programs during the financial crisis to those that did not. Open market repurchases by their very nature are not firm commitments; hence any delay in the open market repurchases will not be met with adverse market reaction. Our expectation, according to the reactive flexibility theory is that the stock market performance of firms that completed all of their repurchase programs during the financial crisis will not be different from the stock market performance of firms that did not complete all of their repurchase programs during the financial crisis. We do not find any evidence that the market treats differently the firms that completed their open market repurchase programs and firms that did not complete their open market repurchase programs. Our inability to reject the hypothesis further supports our contention that repurchases accord the firms with a sense of flexibility that even the market acknowledges.

Overall, we are able to conclude that repurchasers are more flexible than dividend payers. The practical implication for firms that are thinking of initiating a payout program and for those firms that have already initiated a payout program is that repurchases are much more flexible than dividend payments. 


\section{References}

Angelides, Phil 2011, The financial crisis inquiry report, in The Financial Crisis Inquiry Commission, ed.: (U.S. Government Printing Office, Washington, DC).

Banyi, M. L., E. A. Dyl, and K. M. Kahle, 2008, Errors in estimating share repurchases, Journal of Corporate Finance 14, 460-474.

Bozanic, Zahn, 2010, Managerial motivation and timing of open market share repurchases, Review of Quantitative Finance \& Accounting 34, 517-531.

Brav, Alon, John R. Graham, Campbell R. Harvey, and Roni Michaely, 2005, Payout policy in the 21st century, Journal of Financial Economics 77, 483-527.

Cesari, Amedeo De, Susanne Espenlaub, Arif Khurshed, and Michael Simkovic, 2010, The timing of repurchase transactions: The effects of ownership and stock liquidity, (Aston School of Business, Birmingham, U.K.).

Chan, Konan, David L. Ikenberry, and Inmoo Lee, 2007, Do managers time the market? Evidence from open-market share repurchases, Journal of Banking \& Finance 31, 26732694.

Choi, Dosoung, and Sheng-Syan Chen, 1997, The differential information conveyed by share repurchase tender offers and dividend increases, Journal of Financial Research 20, 529.

Christie, William G., 1994, Are dividend omissions truly the cruelest cut of all?, Journal of Financial and Quantitative Analysis 29, 459.

Cook, D. O., L. Krigman, and J. C. Leach, 2004, On the timing and execution of open market repurchases, Review of Financial Studies 17, 463-498.

Cuny, C. J., G. S. Martin, and J. J. Puthenpurackal, 2009, Stock options and total payout, Journal of Financial and Quantitative Analysis 44, 391-410.

Dittmar, Amy K., 2000, Why do firms repurchase stock?, The Journal of Business 73, 331-355.

Fama, Eugene F., and Kenneth R. French, 2001, Disappearing dividends: Changing firm characteristics or lower propensity to pay?, Journal of Financial Economics 60, 3-43.

Feng, G., and N. Liang, 2000, Corporate payout policy and managerial stock incentives, Journal of Financial Economics 57, 385-416.

Grullon, G., and R. Michaely, 2002, Dividends, share repurchases, and the substitution hypothesis, Journal of Finance 57, 1649-1684.

Guay, Wayne, and Jarrad Harford, 2000, The cash-flow permanence and information content of dividend increases versus repurchases, Journal of Financial Economics 57, 385-415.

Healy, Paul M., and Krishna G. Palepu, 1988, Earnings information conveyed by dividend initiations and omissions, Journal of Financial Economics 21, 149-175.

Jagannathan, Murali, and Clifford Stephens, 2003, Motives for multiple open-market repurchase programs, Financial Management 32, 71-91.

Jagannathan, Murali, Clifford P. Stephens, and Michael S. Weisbach, 2000, Financial flexibility and the choice between dividends and stock repurchases, Journal of Financial Economics 57, 355-384.

Kahle, Kathleen M., 2002, When a buyback isn't a buyback: Open market repurchases and employee options, Journal of Financial Economics 63, 235-261.

Lee, B. S., and O. M. Rui, 2007, Time-series behavior of share repurchases and dividends, Journal of Financial and Quantitative Analysis 42, 119-142. 
Liu, Y. I., Samuel H. Szewczyk, and Zaher Zantout, 2008, Underreaction to dividend reductions and omissions?, The Journal of Finance 63, 987-1020.

McNally, William J., 1999, Open market stock repurchase signaling, Financial Management 28, 55-67.

Sant, Rajiv, and Arnold R. Cowan, 1994, Do dividends signal earnings? The case of omitted dividends, Journal of Banking \& Finance 18, 1113-1133.

Skinner, D. J., 2008, The evolving relation between earnings, dividends, and stock repurchases, Journal of Financial Economics 87, 582-609.

Stephens, Clifford P., and Michael S. Weisbach, 1998, Actual share reacquisitions in openmarket repurchase programs, The Journal of Finance 53, 313-333. 
Table I. Summary Statistics

This table provides the summary statistics of firms. SIZE is Sales in millions. $C A S H$ is cash and equivalents. CAPX is capital expenditures. $L E V E R A G E$ is total debt. All three of the former attributes were scaled by total assets. ROA and $R O E$ are net income to total assets and stock holder's equity respectively. $M B$ is the market price of share to book value per share.

\begin{tabular}{|c|c|c|c|c|c|c|c|c|c|c|c|c|}
\hline & \multicolumn{4}{|c|}{ RD Firms } & \multicolumn{4}{|c|}{ RR Firms } & \multicolumn{4}{|c|}{ OR Firms } \\
\hline & Mean & Median & Std Dev. & $\mathrm{N}$ & Mean & Median & Std Dev. & $\mathrm{N}$ & Mean & Median & Std Dev. & $\mathrm{N}$ \\
\hline SIZE & 4273.3700 & 1033.7500 & 6473.3100 & 3592 & 3060.9900 & 855.5735 & 5123.8100 & 3162 & 899.6702 & 139.7769 & 2437.2800 & 4031 \\
\hline CASH & 0.1310 & 0.0743 & 0.1492 & 3592 & 0.1687 & 0.1097 & 0.1654 & 3163 & 0.2335 & 0.1713 & 0.2077 & 4031 \\
\hline LEVERAGE & 0.5553 & 0.5395 & 0.2509 & 3592 & 0.4973 & 0.4805 & 0.2379 & 3163 & 0.4912 & 0.4399 & 0.2905 & 4031 \\
\hline CAPX & 0.0485 & 0.0351 & 0.0423 & 3592 & 0.0415 & 0.0287 & 0.0373 & 3163 & 0.0442 & 0.0266 & 0.0460 & 4031 \\
\hline ROA & -0.0056 & 0.0436 & 0.1775 & 3592 & 0.0209 & 0.0506 & 0.1380 & 3163 & -0.0626 & 0.0158 & 0.2131 & 4031 \\
\hline $\mathrm{ROF}$ & 0.0639 & 0.1089 & 0.3336 & 3592 & 0.0542 & 0.1029 & 0.3050 & 3163 & $\begin{array}{l}-0.0198 \\
\end{array}$ & 0.0574 & 0.3811 & 4031 \\
\hline MB & 2.2191 & 1.7609 & 1.9894 & 3502 & 2.4850 & 1.9680 & 1.9820 & 3126 & 2.2354 & 1.7026 & 2.1405 & 3966 \\
\hline
\end{tabular}




\section{Table II. First Hypothesis}

This table presents the results of Chi-square tests comparing the proportion of RD firms to the proportion of RR firms that reduced payouts during the financial crisis.

Number of firms that paid dividends at least once during the pre-crisis period

Number of firms that reduced dividends in 2008 and 2009

Number of firms that reduced dividends in 2008 and (or ) 2009

Ratio

Number of firms that announced at least one repurchase program during the pre-crisis period

Number of firms that did not announce any program during 2008 and 2009

Number of firms that did not announce any program during 2008 and (or) 2009

Number of firms that announced a lower repurchase program in 2008 and 2009

Number of firms that announced a lower repurchase program in 2008 and (or) 2009

Ratio

\begin{tabular}{|c|c|c|c|}
\hline 641 & 641 & 641 & 641 \\
\hline \multirow[t]{2}{*}{322} & & 322 & \\
\hline & 370 & & 370 \\
\hline $50.23 \%$ & $73.32 \%$ & $50.23 \%$ & $73.32 \%$ \\
\hline \multirow{5}{*}{$\begin{array}{l}433 \\
232\end{array}$} & 433 & 433 & 433 \\
\hline & & & \\
\hline & 386 & & \\
\hline & & 376 & \\
\hline & & & 415 \\
\hline $53.57 \%$ & $89.15 \%$ & $86.83 \%$ & $95.84 \%$ \\
\hline 1.1583 & $124.4339 * * *$ & $152.1658 * * *$ & $190.9428^{* * *}$ \\
\hline
\end{tabular}


Table III. Second Hypothesis

This table provides the results for our second hypothesis. Panel A compares the mean cumulative abnormal returns (CARs) of RD firms that reduced dividends measured as crisis average dividend minus pre crisis average dividend, and RR firms that did not announce a repurchase program in 2008 and 2009. Panel B compares the mean cumulative abnormal returns (CARs) of RD firms that reduced dividends measured as yearly average minus pre crisis average, and RR firms that did not announce a repurchase program in 2008 and (or) 2009. Panel C - Model 1 - 3 presents the results of the regression of CARs of RD firms that reduced dividends based on crisis average minus pre crisis average and RR firms that did not announce any repurchase program during 2008 and 2009 on explanatory variables. Panel C - Model 4-6 presents the results of the regression of CARs of RD firms that reduced dividends based on crisis average dividend minus pre crisis average dividend and RR firms that did not announce any repurchase program during 2008 and (or) 2009 on explanatory variables. The t-test compares whether the mean CARs of RR firms ( $\mathrm{V}_{\mathrm{RR}}$ ) is greater than the mean CARs of RD firms $\left(\mathrm{V}_{\mathrm{RD}}\right)$. The Mann-Whitney-Wilcoxon test compares whether the median CARs of RR firms ( $\mathrm{V}_{\mathrm{RR}}$ ) is greater than the median CARs of RD firms $\left(\mathrm{V}_{\mathrm{RD}}\right)$. The Kolmogorov-Smirnov tests the difference between the maximum point in the distribution of the CARs of RR firms $\left(\mathrm{D}_{\mathrm{RR}}\right)$ and the maximum point in the distribution of the CARs of $\mathrm{RD}$ firms $\left(\mathrm{D}_{\mathrm{RD}}\right) . R D$ is a dummy variable that takes the value of one if the firm is a RD firm. PAYOUT REDUCTION is the crisis average payout minus the pre-crisis average payout. SIZE is the log of total sales. T-statistics are provided in parenthesis. White's heteroskedasticity consistent standard errors are employed. Coefficients significant at the $1 \%$, $5 \%$, and $10 \%$ are designated by ***, **, and * respectively. All variables are winsorized at the $5 \%$ level.

\section{Panel A}

\begin{tabular}{lrrrr} 
& \multicolumn{1}{c}{ Mean } & Median & Std Dev & $\mathrm{N}$ \\
\cline { 2 - 5 } Cumulative Abnormal Returns of RR firms & 0.5579 & 0.4663 & 0.7418 & 153 \\
Cumulative Abnormal Returns of RD firms & 0.2094 & 0.1379 & 0.8127 & 153 \\
T Statistic Value $\left(\mathrm{V}_{\mathrm{RR}}>\mathrm{V}_{\mathrm{RD}}\right)$ & $3.9176^{* * *}$ & & & \\
Mann Whitney Wilcoxon Statistic Value $\left(\mathrm{V}_{\mathrm{RR}}=\mathrm{V}_{\mathrm{RD}}\right)$ & & & & \\
Kolmogorov-Smirnov Test P-Value $\left(\mathrm{D}_{\mathrm{RR}}=\mathrm{D}_{\mathrm{RD}}\right)$ & \multicolumn{3}{c}{$0.2353^{* * * *}$} \\
\end{tabular}

Panel B

\begin{tabular}{|c|c|c|c|c|}
\hline \multirow{2}{*}{ 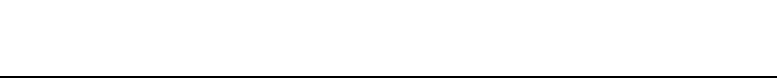 } & \\
\hline & Mean & Median & Std Dev & $\mathrm{N}$ \\
\hline Cumulative Abnormal Returns of RR firms & 0.4376 & 0.3596 & 0.7077 & 270 \\
\hline Cumulative Abnormal Returns of RD firms & 0.2250 & 0.1822 & 0.7565 & 182 \\
\hline T Statistic Value $\left(\mathrm{V}_{\mathrm{RR}}>\mathrm{V}_{\mathrm{RD}}\right)$ & $3.0455 * * *$ & & & \\
\hline Mann Whitney Wilcoxon Statistic Value $\left(\mathrm{V}_{\mathrm{RR}}=\mathrm{V}_{\mathrm{RD}}\right)$ & & $3.249 * * *$ & & \\
\hline Kolmogorov-Smirnov Test P-Value $\left(\mathrm{D}_{\mathrm{RR}}=\mathrm{D}_{\mathrm{RD}}\right)$ & & $0.1573 * * *$ & & \\
\hline
\end{tabular}


Panel C

\begin{tabular}{lcccccc}
\hline Dependent Variable: CARs & $(1)$ & $(2)$ & $(3)$ & $(4)$ & $(5)$ & $(6)$ \\
\hline RD & $-0.3485^{* * *}$ & $-0.3449^{* * *}$ & $-0.3417^{* * *}$ & $-0.2126^{* * *}$ & $-0.2128^{* * *}$ & $-0.2130^{* * *}$ \\
& $(-3.9048)$ & $(-3.8560)$ & $(-3.8031)$ & $(-2.9989)$ & $(-3.0038)$ & $(-3.0022)$ \\
PAYOUT REDUCTION & & 0.2086 & 0.1624 & & -0.0152 & -0.0132 \\
& & $(0.6316)$ & $(0.4900)$ & & $(-0.0527)$ & $(-0.0458)$ \\
SIZE & & & -0.0232 & & & 0.0014 \\
& & & $(-0.9545)$ & & & $(0.0686)$ \\
Constant & & & & & $0.4265^{* * *}$ \\
& $0.5580^{* * *}$ & $0.5798^{* * *}$ & $0.7455^{* * *}$ & $0.4376^{* * *}$ & $0.4366^{* * *}$ & $(2.6479)$ \\
NOBS & $(9.2733)$ & $(7.8145)$ & $(3.9691)$ & $(10.1424)$ & $(8.6600)$ & 452 \\
R-squared & & & & & & \\
F-Value & 306 & 306 & 306 & 452 & 452 & 0.0202 \\
& 0.0481 & 0.0492 & 0.0515 & 0.0202 & 0.0202 & $3.01^{* *}$ \\
\hline
\end{tabular}


Table IV. Third Hypothesis

This table provides the results for our third hypothesis. Panel A compares the mean CARs of RD firms that reduced dividends measured as yearly dividend minus pre crisis average dividend, and RR firms that announced a lower repurchase value in 2008 and 2009 . Panel B compares the mean cumulative abnormal returns (CARs) of RD firms that reduced dividends measured as yearly average minus pre crisis average, and RR firms that announced a lower repurchase value in 2008 and (or) 2009. Panel C - Models 1 - 3 present the results of the regression of CARs of RD firms that reduced dividends based on crisis average minus pre crisis average and RR firms that announced a lower repurchase value during 2008 and 2009 on explanatory variables. Panel C - Models 4-6 presents the results of the regression of CARs of RD firms that reduced dividends based on crisis average dividend minus pre crisis average dividend and RR firms that announced a lower repurchase value during 2008 and (or) 2009 on explanatory variables. The t-test compares whether the mean CARs of RR firms ( $\left.V_{\mathrm{RR}}\right)$ is greater than the mean CARs of RD firms ( $\left.\mathrm{V}_{\mathrm{RD}}\right)$. The Mann-WhitneyWilcoxon test compares whether the median CARs of RR firms $\left(\mathrm{V}_{\mathrm{RR}}\right)$ is greater than the median CARs of RD firms ( $\left.\mathrm{V}_{\mathrm{RD}}\right)$. The KolmogorovSmirnov tests the difference between the maximum point in the distribution of the CARs of RR firms $\left(\mathrm{D}_{\mathrm{RR}}\right)$ and the maximum point in the distribution of the CARs of RD firms ( $\left.\mathrm{D}_{\mathrm{RD}}\right) . R D$ is a dummy variable that takes the value of one if the firm is a RD firm. PAYOUT REDUCTION is the crisis average payout minus the pre-crisis average payout. SIZE is the log of total sales. T-statistics are provided in parenthesis. White's heteroskedasticity consistent standard errors are employed. Coefficients significant at the $1 \%, 5 \%$, and $10 \%$ are designated by ***, **, and * respectively. All variables are winsorized at the $5 \%$ level.

\section{Panel A}

\begin{tabular}{|c|c|c|c|c|}
\hline & \\
\hline & Mean & Median & Std Dev & $\mathrm{N}$ \\
\hline Cumulative Abnormal Returns of RR firms & 0.4699 & 0.4508 & 0.7025 & 258 \\
\hline Cumulative Abnormal Returns of RD firms & 0.2094 & 0.1379 & 0.8127 & 153 \\
\hline $\mathrm{T}$ Statistic Value $\left(\mathrm{V}_{\mathrm{RR}}>\mathrm{V}_{\mathrm{RD}}\right)$ & $3.5605^{* * *}$ & & & \\
\hline Mann Whitney Wilcoxon Statistic Value $\left(\mathrm{V}_{\mathrm{RR}}=\mathrm{V}_{\mathrm{RD}}\right)$ & & $3.803^{* * *}$ & & \\
\hline Kolmogorov-Smirnov Test P-Value $\left(\mathrm{D}_{\mathrm{RR}}=\mathrm{D}_{\mathrm{RD}}\right)$ & & $0.2003 * * *$ & & \\
\hline
\end{tabular}

Panel B

\begin{tabular}{|c|c|c|c|c|}
\hline & \\
\hline & Mean & Median & Std Dev & $\mathrm{N}$ \\
\hline Cumulative Abnormal Returns of RR firms & 0.3299 & 0.2610 & 0.5914 & 291 \\
\hline Cumulative Abnormal Returns of RD firms & 0.2250 & 0.1822 & 0.7565 & 182 \\
\hline T Statistic Value $\left(\mathrm{V}_{\mathrm{RR}}>\mathrm{V}_{\mathrm{RD}}\right)$ & $1.9074 * *$ & & & \\
\hline Mann Whitney Wilcoxon Statistic Value $\left(\mathrm{V}_{\mathrm{RR}}=\mathrm{V}_{\mathrm{RD}}\right)$ & & $2.158^{* *}$ & & \\
\hline Kolmogorov-Smirnov Test P-Value $\left(\mathrm{D}_{\mathrm{RR}}=\mathrm{D}_{\mathrm{RD}}\right)$ & & $0.1757 * * *$ & & \\
\hline
\end{tabular}


Panel C

\begin{tabular}{|c|c|c|c|c|c|c|}
\hline Dependent Variable: CARs & (1) & (2) & (3) & (4) & (5) & (6) \\
\hline $\mathrm{RD}$ & $\begin{array}{c}-0.2675^{* * *} \\
(-3.4454)\end{array}$ & $\begin{array}{c}-0.2685^{* * *} \\
(-3.4142)\end{array}$ & $\begin{array}{c}-0.2681^{* * *} \\
(-3.4018)\end{array}$ & $\begin{array}{l}-0.1156^{*} \\
(-1.8230)\end{array}$ & $\begin{array}{l}-0.1152 * \\
(-1.8130)\end{array}$ & $\begin{array}{l}-0.1088^{*} \\
(-1.7168)\end{array}$ \\
\hline PAYOUT REDUCTION & & $\begin{array}{c}-0.0289 \\
(-0.0924)\end{array}$ & $\begin{array}{c}-0.0351 \\
(-0.1124)\end{array}$ & & $\begin{array}{c}0.0254 \\
(0.0971)\end{array}$ & $\begin{array}{c}-0.0212 \\
(-0.0831)\end{array}$ \\
\hline SIZE & & & $\begin{array}{c}-0.0041 \\
(-0.1988)\end{array}$ & & & $\begin{array}{c}-0.0422 * * \\
(-2.4270)\end{array}$ \\
\hline Constant & $\begin{array}{c}0.4700^{* * *} \\
(10.7247)\end{array}$ & $\begin{array}{c}0.4677^{* * *} \\
(8.6757)\end{array}$ & $\begin{array}{c}0.4972 * * * \\
(3.0443)\end{array}$ & $\begin{array}{c}0.3299 * * * \\
(9.4995)\end{array}$ & $\begin{array}{c}0.3316 * * * \\
(8.2810)\end{array}$ & $\begin{array}{c}0.6394 * * * \\
(4.4972)\end{array}$ \\
\hline NOBS & 411 & 411 & 411 & 473 & 473 & 473 \\
\hline R-squared & 0.0301 & 0.0301 & 0.0302 & 0.0077 & 0.0077 & 0.0191 \\
\hline F-Value & $11.87 * * *$ & $5.91 * * *$ & $3.93^{* * *}$ & $3.32 *$ & 1.66 & $2.92 * *$ \\
\hline
\end{tabular}


Table V-A. Fourth Hypothesis - Amount Spent on Repurchases

This table presents the results of our fifth hypothesis. Panel A and B present the results for RR firms and OR firms. The t-test compares whether the mean of the maximum amount spent on repurchases scaled by mean total assets ( $\mathrm{V}_{\text {crisis }}$ ) by $\mathrm{RR}(\mathrm{OR})$ firms during the crisis was greater than mean of the maximum amount spent on repurchases scaled by mean total assets ( $\left.\mathrm{V}_{\text {pre-crisis }}\right)$ by $\mathrm{RR}(\mathrm{OR})$ firms prior to the crisis. The Mann-WhitneyWilcoxon test compares whether the median of the maximum amount spent on repurchases $\left(\mathrm{V}_{\text {crisis }}\right)$ by $R R(O R)$ firms during crisis was equal to median of the maximum amount spent on repurchases scaled by mean total assets $\left(\mathrm{V}_{\text {pre-crisis }}\right)$ by RR (OR) firms prior to the crisis. The Kolmogorov-Smirnov tests the difference in the maximum value of the distribution of the maximum amount spent on repurchases scaled by mean total assets ( $\mathrm{D}_{\text {crisis }}$ ) by RR (OR) firms during the crisis and the maximum value of the distribution of the maximum amount spent on repurchases scaled by mean total assets $\left(D_{\text {pre-crisis }}\right)$ by $R R(O R)$ firms prior to the crisis.

Panel A - RR firms

Amount spent by RR firms on repurchases Prior to the Crisis

Amount spent by RR firms on repurchases During the Crisis

T Statistic Value (Vpre-crisis $>$ Vcrisis)

Mann Whitney Wilcoxon Statistic Value (Vcrisis = Vpre-crisis)

\begin{tabular}{rrrr}
\hline \multicolumn{1}{c}{ Mean } & \multicolumn{1}{c}{ Median } & Std Dev & \multicolumn{1}{c}{$\mathrm{N}$} \\
\hline 0.1029 & 0.0732 & 0.0947 & 850 \\
0.0829 & 0.0428 & 0.1010 & 1015 \\
$4.3844^{* * *}$ & & & \\
& & & \\
& & & \\
& $0.324^{* * *}$ & & \\
\hline
\end{tabular}

Panel B - OR firms

\begin{tabular}{|c|c|c|c|c|}
\hline & \\
\hline & Mean & Median & Std Dev & $\mathrm{N}$ \\
\hline Amount spent by OR firms on repurchases Prior to the Crisis & 0.0892 & 0.0651 & 0.0812 & 412 \\
\hline Amount spent by OR firms on repurchases During the Crisis & 0.0639 & 0.0264 & 0.0864 & 709 \\
\hline T Statistic Value (Vpre-crisis>Vcrisis) & $4.8838 * * *$ & & & \\
\hline Mann Whitney Wilcoxon Statistic Value (Vcrisis = Vpre-crisis) & & $8.398 * * *$ & & \\
\hline Kolmogorov-Smirnov Test P-Value (Dcrisis = Dpre-crisis) & & $0.3189 * * *$ & & \\
\hline
\end{tabular}




\section{Table V-B. Fourth Hypothesis - Fraction of Shares Repurchased}

This table presents the results of our fifth hypothesis. Panel A and B present the results for RR firms and OR firms. The t-test compares whether the maximum of the number of shares purchased scaled by total shares sought under each program ( $\mathrm{V}_{\text {crisis }}$ ) by RR (OR) firms during the crisis was greater than the maximum number of shares purchased scaled by total shares sought under each program ( $\left.V_{\text {pre-crisis }}\right)$ by $R R(O R)$ firms prior to the crisis. The Mann-Whitney-Wilcoxon test compares whether the median of the maximum of the number shares purchased scaled by total shares sought under each program $\left(\mathrm{V}_{\text {crisis }}\right)$ by $\mathrm{RR}(\mathrm{OR})$ firms during crisis was equal to median of the maximum number of shares purchased scaled by total shares sought under each program $\left(\mathrm{V}_{\text {pre- }}\right.$ crisis) by RR (OR) firms prior to the crisis. The Kolmogorov-Smirnov tests the difference in the maximum value of the distribution of the maximum number of shares purchased scaled by total shares sought under each program ( $\mathrm{D}_{\text {crisis }}$ ) by RR (OR) firms during the crisis and the maximum value of the distribution of the maximum number of shares purchased scaled by total shares sought under each program ( $\left.\mathrm{D}_{\text {pre-crisis }}\right)$ by $\mathrm{RR}(\mathrm{OR})$ firms prior to the crisis.

Panel A - RR firms

\begin{tabular}{|c|c|c|c|c|}
\hline & & & & \\
\hline & Mean & Median & Std Dev & $\mathrm{N}$ \\
\hline Shares repurchased by RR firms on repurchases Prior to the Crisis & 0.9011 & 0.8658 & 0.6318 & 850 \\
\hline Shares repurchased by RR firms on repurchases During the Crisis & 0.6992 & 0.5829 & 0.7113 & 1015 \\
\hline T Statistic Value (Vpre-crisis>Vcrisis) & $6.4222^{* * *}$ & & & \\
\hline Mann Whitney Wilcoxon Statistic Value (Vcrisis = Vpre-crisis) & & $8.646 * * *$ & & \\
\hline Kolmogorov-Smirnov Test P-Value (Dcrisis = Dpre-crisis) & & $0.2196 * * *$ & & \\
\hline
\end{tabular}

Panel B-OR firms

\begin{tabular}{|c|c|c|c|c|}
\hline & \\
\hline & Mean & Median & Std Dev & $\mathrm{N}$ \\
\hline Shares repurchased by OR firms on repurchases Prior to the Crisis & 0.7504 & 0.6792 & 0.5684 & 412 \\
\hline Shares repurchased by OR firms on repurchases During the Crisis & 0.5148 & 0.3289 & 0.5732 & 709 \\
\hline T Statistic Value (Vpre-crisis>Vcrisis) & $6.6551^{* * *}$ & & & \\
\hline Mann Whitney Wilcoxon Statistic Value (Vcrisis = Vpre-crisis) & & $7.592 * * *$ & & \\
\hline Kolmogorov-Smirnov Test P-Value (Dcrisis = Dpre-crisis) & & $0.2889 * * *$ & & \\
\hline
\end{tabular}




\section{Table VI. Fifth Hypothesis}

This table presents the results of our fifth hypothesis. Panel A compares the mean cumulative abnormal returns (CARs) of RR firms that completed their repurchase programs during the financial crisis and those that did not. Panel B compares the mean cumulative abnormal returns (CARs) of OR firms that completed their repurchase programs during the financial crisis and those that did not. The t-test compares whether the CARs $\left(\mathrm{V}_{\text {complete }}\right)$ of $\mathrm{RR}(\mathrm{OR})$ firms that completed their repurchase programs during the financial crisis to the CARs ( $\mathrm{V}_{\text {inomplete }}$ ) of RR (OR) firms that did not complete their repurchase programs during the financial crisis. The MannWhitney-Wilcoxon test compares whether the median CARs of ( $\left.\mathrm{V}_{\text {complete }}\right) \mathrm{RR}(\mathrm{OR})$ firms that completed their repurchase programs during crisis was equal to the median CARs ( $V_{\text {incomplete }}$ of $R R(O R)$ firms that did not complete their repurchase programs during the financial crisis. The Kolmogorov-Smirnov tests the difference in the maximum value of the distribution of the CARs $\left(D_{\text {complete }}\right)$ of $R R$ (OR) that completed their repurchase programs during the crisis and the maximum value of the distribution CARs ( $\mathrm{D}_{\text {incomplete }}$ ) of RR (OR) that did not complete their repurchase programs during the crisis. Panel C - Models 1 \& 2 present the results of the regression of CARs, of RR firms that completed their repurchase programs during the financial crisis and those that did not, on explanatory variables. Panel C - Models 3 \& 4 present the results of the regression of CARs, of OR firms that completed their repurchase programs during the financial crisis and those that did not, on explanatory variables. COMPLETE is a dummy variable that takes the value of one if the firm did not complete its repurchase program. SIZE is the log of total sales. White's heteroskedasticity consistent standard errors are employed. Coefficients significant at the $1 \%, 5 \%$, and $10 \%$ are designated by $* * *, * *$, and * respectively. All variables are winsorized at the $5 \%$ level.

\section{Panel A}

\begin{tabular}{|c|c|c|c|c|}
\hline & \\
\hline & Mean & Median & Std Dev & $\mathrm{N}$ \\
\hline $\begin{array}{l}\text { Cumulative Abnormal Returns of RR firms that completed the } \\
\text { repurchase programs }\end{array}$ & 0.3090 & 0.2643 & 0.5880 & 156 \\
\hline $\begin{array}{l}\text { Cumulative Abnormal Returns of RR firms that did not complete the } \\
\text { repurchase programs }\end{array}$ & 0.2791 & 0.2277 & 0.5954 & 207 \\
\hline T Statistic Value $\left(\mathrm{V}_{\mathrm{RR}}>\mathrm{V}_{\mathrm{RD}}\right)$ & 0.4766 & & & \\
\hline Mann Whitney Wilcoxon Statistic Value $\left(\mathrm{V}_{\mathrm{RR}}=\mathrm{V}_{\mathrm{RD}}\right)$ & & 0.550 & & \\
\hline
\end{tabular}




\section{Panel B}

\begin{tabular}{|c|c|c|c|c|}
\hline & \multirow[b]{2}{*}{ Mean } & & & \\
\hline & & Median & Std Dev & $\mathrm{N}$ \\
\hline $\begin{array}{l}\text { Cumulative Abnormal Returns of OR firms that completed the } \\
\text { repurchase programs }\end{array}$ & 0.3370 & 0.3310 & 0.8077 & 82 \\
\hline $\begin{array}{l}\text { Cumulative Abnormal Returns of OR firms that did not complete the } \\
\text { repurchase programs }\end{array}$ & 0.1722 & 0.1873 & 0.8209 & 100 \\
\hline T Statistic Value $\left(\mathrm{V}_{\mathrm{RR}}>\mathrm{V}_{\mathrm{RD}}\right)$ & 1.3577 & & & \\
\hline Mann Whitney Wilcoxon Statistic Value $\left(\mathrm{V}_{\mathrm{RR}}=\mathrm{V}_{\mathrm{RD}}\right)$ & & 1.110 & & \\
\hline Kolmogorov-Smirnov Test P-Value $\left(\mathrm{D}_{\mathrm{RR}}=\mathrm{D}_{\mathrm{RD}}\right)$ & & 0.1276 & & \\
\hline
\end{tabular}

\section{Panel C}

\begin{tabular}{lcccc}
\hline Dependent Variable: CARs & $(1)$ & $(2)$ & $(3)$ & $(4)$ \\
\hline COMPLETE & 0.0299 & 0.0310 & 0.1649 & 0.1634 \\
& $(0.4761)$ & $(0.4907)$ & $(1.3523)$ & $(1.3212)$ \\
SIZE & & -0.0055 & & -0.0110 \\
& & $(-0.2775)$ & & $(-0.2372)$ \\
Constant & $0.2791^{* * *}$ & $0.3180^{* *}$ & $0.1722^{* *}$ & 0.2378 \\
& $(6.7286)$ & $(2.0775)$ & $(2.0872)$ & $(0.7700)$ \\
NOBS & & & & \\
R-squared & 363 & 363 & 182 & 182 \\
F-value & 0.0006 & 0.0008 & 0.0101 & 0.0105 \\
\hline & 0.23 & 0.15 & 1.83 & 1.01 \\
\hline
\end{tabular}




\section{Appendix 1}

Financial Crisis Timeline - This table provides the beginning and ending period of the financial crisis based on three different sources of information.

\begin{tabular}{lll}
\hline Identification Method & Beginning Quarter & Ending Quarter \\
\hline St. Louis Fed Timeline & Q3 2007 & Q4 2009 \\
NBER & Q1 2008 & Q2 2009 \\
Dow Jones & Q1 2008 & Q1 2009 \\
\hline
\end{tabular}




\section{Appendix 2}

Calculation of the Maximum Amount Spent on Share Repurchases

\begin{tabular}{|c|c|c|c|c|c|c|c|c|}
\hline Month & Year & $\begin{array}{r}\text { Share } \\
\text { Repurchase } \\
\text { Announcement } \\
\text { Amount }\end{array}$ & $\begin{array}{r}\text { Number of } \\
\text { Shares } \\
\text { Sought }\end{array}$ & $\begin{array}{r}\text { Number of } \\
\text { Shares } \\
\text { Repurchased }\end{array}$ & $\begin{array}{l}\text { Amount Spent on } \\
\text { Share Repurchases }\end{array}$ & Total Assets & $\begin{array}{l}\text { Scaled } \\
\text { Value }\end{array}$ & $\begin{array}{r}\text { Cumulative } \\
\text { Amount } \\
\text { spent on } \\
\text { share } \\
\text { repurchases }\end{array}$ \\
\hline January & 2008 & $\$ 100,000,000$ & $10,000,000$ & 1000000 & $\$ 10,000,000.00$ & $\$ 2,000,000,000.00$ & $0.500 \%$ & $0.500 \%$ \\
\hline February & 2008 & & & 2000000 & $\$ 20,000,000.00$ & $\$ 2,000,000,000.00$ & $1.000 \%$ & $1.500 \%$ \\
\hline March & 2008 & & & 1000000 & $\$ 10,000,000.00$ & $\$ 2,000,000,000.00$ & $0.500 \%$ & $2.000 \%$ \\
\hline April & 2008 & & & 2000000 & $\$ 20,000,000.00$ & $\$ 2,000,000,000.00$ & $1.000 \%$ & $3.000 \%$ \\
\hline May & 2008 & & & 3000000 & $\$ 30,000,000.00$ & $\$ 2,000,000,000.00$ & $1.500 \%$ & $4.500 \%$ \\
\hline June & 2008 & & & 1000000 & $\$ 10,000,000.00$ & $\$ 2,000,000,000.00$ & $0.500 \%$ & $5.000 \%$ \\
\hline July & 2008 & $\$ 100,000,000$ & $10,000,000$ & 1000000 & $\$ 10,000,000.00$ & $\$ 2,000,000,000.00$ & $0.500 \%$ & $0.500 \%$ \\
\hline August & 2008 & & & 3500000 & $\$ 35,000,000.00$ & $\$ 2,000,000,000.00$ & $1.750 \%$ & $2.250 \%$ \\
\hline September & 2008 & & & 2000000 & $\$ 20,000,000.00$ & $\$ 2,000,000,000.00$ & $1.000 \%$ & $3.250 \%$ \\
\hline October & 2008 & & & 1500000 & $\$ 15,000,000.00$ & $\$ 2,000,000,000.00$ & $0.750 \%$ & $4.000 \%$ \\
\hline November & 2008 & & & 1500000 & $\$ 15,000,000.00$ & $\$ 2,000,000,000.00$ & $0.750 \%$ & $4.750 \%$ \\
\hline December & 2008 & & & 0 & - & & & \\
\hline
\end{tabular}

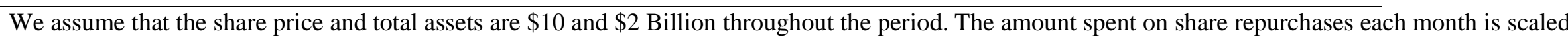
by total assets. The maximum amount spent on share repurchases in the first program is $5.5 \%$ of total assets. Similarly, the maximum amount spent on share repurchases in the second program is $4.75 \%$ of total assets. To calculate the maximum number of share repurchased, the number of shares repurchased each month is scaled by the number of shares sought at the announcement and the above process is repeated. 
